\title{
Patterns of range size in New Zealand ferns and lycophytes
}

\author{
Catherine F. Mountier ${ }^{1}$, Bradley S. Case ${ }^{2}$, Leon Perrie ${ }^{3}$, Patrick Brownsey ${ }^{3}$, Adrian M. Paterson ${ }^{1}$, \\ Timothy J. Curran ${ }^{1}$ and Hannah L. Buckley ${ }^{2 *}$ \\ ${ }^{1}$ Department of Pest-management and Conservation, Lincoln University, Lincoln, New Zealand \\ ${ }^{2}$ School of Science, Auckland University of Technology, Auckland, New Zealand \\ ${ }^{3}$ Museum of New Zealand Te Papa Tongarewa, Wellington, New Zealand \\ *Author for correspondence (Email: Hannah.Buckley@aut.ac.nz)
}

Published online: 9 May 2018

\begin{abstract}
We describe spatial patterns in the geographic ranges of all New Zealand ferns and lycophytes, test if range sizes are correlated with phylogeny, and identify ecological characteristics related to their range sizes. Herbarium records for all species of fern and lycophyte in New Zealand were used to generate distribution maps and estimate range sizes by summing the area of occupied ecological districts. Trait, habitat, biostatus, and distribution data were compiled from the literature and DNA sequence data were obtained for each species. Species' range sizes varied between $356 \mathrm{~km}^{2}$ and the entire country $\left(266067 \mathrm{~km}^{2}\right)$. The range size frequency distribution for New Zealand ferns was right skewed and bimodal, showing that although most species have small ranges, there is a smaller, core group of very widely distributed species. Larger range sizes were most associated with species that were native, epiphytic, habitat generalists, and which occurred across a large altitudinal extent. The range size of introduced species was positively related to both the number of years since arrival in New Zealand, and the number of global regions they occur in.
\end{abstract}

Keywords: biogeography; commonness; distributions; ferns; geometric constraint; lycophytes; monilophytes; range size; Rapoport's rule; rarity

\section{Introduction}

Exploring large-scale patterns in species distributions contributes to our understanding of the factors that generate ecological patterns in species' current distributions (Gaston 1994; Estrada et al. 2016) and provide data that underpin our ability to understand and predict the effects of climate change on biotas (e.g. Davis \& Shaw 2001; Reich et al. 2015). Such macroecological studies across a range of taxa and spatial scales have revealed global consistencies in the spatial patterns of species' range sizes. For instance, although large variation exists in species' range sizes within floras and faunas, and most species within biotas are relatively rare (Gaston 1996), ranges decrease in size closer to the equator ('Rapoport's Rule'; Janzen 1967; Rapoport 1982; Stevens 1989). Despite these repeated patterns, there is good evidence that the processes causing variation in species' range sizes are context-dependent (Rabinowitz 1981), scale-dependent (Gaston 1994), and likely the result of more than one process (Kunin \& Gaston 1997). For example, individual species' characteristics can predict variation in occupancy and range size (Buckley \& Freckleton 2010, Diamond et al.2011). Consequently, relating features of species, such as their morphology, ecology and phylogenetic relatedness, to their range sizes allows us to determine if and how we can use knowledge of species' traits and life histories to aid in understanding these patterns. Knowing what traits and other factors are associated with range size may lead to generalisations or system-specific knowledge that can be applied in the conservation and management of species at risk of climate change effects. This is particularly useful in speciose communities, where obtaining detailed understanding of the autecology of large numbers of species is not feasible.

Ferns and lycophytes (hereafter, ferns; see Pryer et al. 2004; PPG I 2016) are a useful taxonomic group for macroecological studies due to their wide variation in geographic range sizes (Kessler 2010), life history traits, and habitat preferences (Kessler 2010; Nagalingum et al. 2015). Most fern macroecology has focussed on patterns in species diversity; however, geographic distributions of ferns have been observed to be wider than those of other taxa (McGlone et al. 2001) and to be closely tied to climatic variation and vegetation type boundaries (e.g. Ramírez-Barahona \& LunaVega 2015). These observations are thought to be related to life history characteristics, such as reproductive strategies and environmental tolerances, making ferns possible candidates as indicator species of global change.

Many aspects of fern reproductive biology contribute to their ability to disperse and establish, and therefore, potentially influence their geographic ranges. The two "alternate generations" (sporophyte and gametophyte) of ferns are free-living: the adult plant, the sporophyte, produces asexual spores which germinate into gametophytes, and it is in this stage that fertilisation occurs, producing a new sporophyte. Gametophytes, the highly understudied life stage, are very small, usually short-lived, and free water is essential for their fertilisation (Brownsey \& Smith-Dodsworth 2000, Sharpe \& Mehltreter 2010), potentially limiting the probability of establishment. Ferns have numerous, small, light-weight, widely-dispersed spores (Tryon 1970), which are capable of long-distance dispersal (sensu Nathan 2006; Brownsey 2001; Kessler 2010). The majority of ferns are homosporous and can both cross-fertilise and self-fertilise, so that a single spore can potentially establish a new population, a feature that may be advantageous after a long-distance dispersal event (Barrington 1993; Kessler 2010). Ferns as a group exhibit a variety of reproductive modes: sexual, vegetative, and apogamous (development of an embryo without fertilisation), and many ferns are capable of more than one mode, which 
has been shown to positively influence range size (Guo et al. 2003; Wickell et al. 2017).

Given that dispersal limitation (in contrast to establishment limitation) is not thought to be important in limiting the distributions of most ferns, the interaction of habitat factors, such as moisture availability and temperature, with individual species' preferences and tolerances are the key determinants of fern establishment, and consequently, their range sizes (Tryon 1970, 1986; Richard et al. 2000; Smith et al. 2006; Brock et al. 2016). For instance, most ferns have brown spores, but some are green or yellow and contain chlorophyll. These chlorophyllous spores are more vulnerable to climatic extremes and less persistent than brown spores (Page 2002). Some fern species have strong preferences for particular soil, light and moisture conditions (Brownsey \& Smith-Dodsworth 2000; Arens 2001) and some epiphytic ferns are host-specific (Mehltreter et al. 2005). Such habitat specialists are most likely to have restricted range sizes, particularly if their preferred habitat only occurs in relatively small, geographically isolated areas (Peck et al. 1990; Kessler 2010). Further, polyploidy is common among ferns and, although the advantages and disadvantages of polyploidy are not well understood, it has been suggested that polyploid species may have more potential to adapt to a wider range of environmental conditions (Marchant et al. 2016), or may be more competitive than diploid species (Pandit et al. 2011). Thus, polyploidy may be a causal factor in fern range sizes.

The three main islands of New Zealand host 248 species of ferns (Breitweiser et al. 2009). Of these, 196 are native and 52 have been introduced since Europeans arrived about 250 years ago (Breitweiser et al. 2009). There are 76 genera, of which 16 are represented only by introduced species, and 31 families, three of which contain only introduced species. The rate of endemism in ferns in New Zealand is $44 \%$, about half the rate of endemism for seed plants (Breitweiser et al. 2009). There are only a few geographically restricted, "narrow" endemic ferns in New Zealand (Brownsey 2001), almost half of which occur on isolated islands. Several introduced species have spread and become problem weeds, such as Selaginella kraussiana, Dryopteris filix-mas (both introduced as ornamentals) and Equisetum arvense (introduced accidentally), but many others are only noted in occasional records as garden "escapees" (Breitweiser et al. 2009).

Brownsey (2001) showed that many New Zealand ferns have wide geographical ranges and thus their dispersal does not appear to have been constrained by geographical barriers within New Zealand. There is a relationship between climatic gradients (mean annual temperature and rainfall) and fern distribution patterns (Lehmann et al. 2002; Zaniewski et al. 2002). For a few species, geothermal environments influence distributions by either excluding species, or providing specialist habitats (Brownsey 2001). More fern speciation has occurred in cool forest environments than in the alpine zones, which are the hotspot of many of New Zealand's flowering plant radiations (Winkworth et al. 2005). Consequently, more of New Zealand's endemic ferns have southern distributions. Some species that are widespread in other countries appear to be constrained to the warm temperate areas of northern New Zealand by climate (Brownsey 2001).

Here, we build on these previous works by quantitatively assessing spatial patterns in the range sizes of all New Zealand ferns across the whole country. New Zealand ferns are ideal for studying species' distribution patterns because of the variability in life histories, habitat preferences, and distribution patterns within a flora that is of manageable size and wellknown taxonomically and botanically (Brownsey \& SmithDodsworth 2000; Breitweiser et al. 2009). New Zealand spans a broad latitudinal range from $34^{\circ}$ to $47^{\circ}$, has mountainous topography and a long coastline, which provides high habitat diversity. Ecologically and biogeographically, New Zealand ferns are an understudied group, but are potentially valuable indicators of the particular environmental changes predicted for New Zealand with climate change, such as increased dryness in eastern areas. In this paper, we ask: (1) What patterns are there in the New Zealand geographic ranges of fern species? (2) What factors (life history traits, habitat, distribution, and biostatus) are correlated with range size in New Zealand ferns? (3) Do phylogenetically closely-related New Zealand ferns have similar range sizes?

\section{Methods}

\section{Data collection}

A dataset compiled from herbarium records was used to map distributions of individual New Zealand fern species on the three main islands (North, South and Stewart), and to calculate range sizes. Range data were obtained for all fern species in New Zealand using data from three herbaria in 2013: Te Papa (WELT), Auckland War Memorial Museum (AK) and the Allan Herbarium (CHR) at Landcare Research in Lincoln. Species' names and synonyms were updated and standardised to align with the Te Papa fern list (Brownsey \& Perrie 2013b) and recent taxonomic revisions (Brownsey et al. 2013; Brownsey \& Perrie 2013a; Perrie et al. 2013; Perrie et al. 2014). Sub-species were combined for the purpose of this study, with the exceptions of Asplenium appendiculatum subspecies appendiculatum and $A$. a. maritimum, Asplenium flaccidum subspecies flaccidum and A.f. haurakiense, Dicksonia lanata subspecies lanata and D. l. hispida, Notogrammitis angustifolia subspecies angustifolia and N. a. nothofageti, and Polystichum neozelandicum subspecies neozelandicum and P.n.zerophyllum, which were all considered to be ecologically and/or spatially distinct enough to be considered separately. Specimens that were hybrids or had an inconclusive identification were excluded. Thus, the full dataset contained 255 taxa (including subspecies), of which 92 taxa were endemic (36\%), 112 were native but not endemic (44\%) and 50 were introduced (20\%) (see Appendix S1 in Supplementary Material). Ten species were removed prior to analysis because they occurred only on offshore islands, and a further 32 were removed because they were classified as 'casuals', meaning introduced species that self-propagated in New Zealand, but were not yet fully naturalised. The analysed dataset therefore contained 212 taxa (hereafter, species), within 65 genera and 30 families.

To quantify species' ranges, point locations obtained from databased herbarium records were used to create GIS point maps for each species. These maps were individually checked against documented distributions (e.g. Brownsey \& SmithDodsworth 2000) and edited using expert knowledge (LP and $\mathrm{PB})$. Anomalous records were discarded if their identification and/or location could not be verified. These updated datasets were used, in combination with the GIS layer of New Zealand Ecological Districts $(n=268$; McEwen 1987), to calculate the area of occupied ecological districts within the three main islands (North, South and Stewart). Second, using the updated herbarium-based point locations layer, the latitudinal maximum, midpoint, minimum and extent for each species were extracted. 
We correlated range sizes of New Zealand native and introduced fern taxa with trait, habitat, and biostatus data compiled from literature sources (Tagawa \& Iwatsuki 1989, Flora of North America Editorial Committee 1993, Brownsey \& Smith-Dodsworth 2000, eFloras 2014, Brownsey et al. 2013, Perrie \& Brownsey 2012, Perrie et al. 2012, Perrie et al. 2013, Perrie et al. 2014). The choice of data was based on hypotheses about the factors thought to be important for fern range sizes (Table 1). Trait data included (Appendix S2): polyploidy (or not), spore colour (green or brown), heterosporosity (or homosporosity), frond dimorphism (different reproductive fronds), presence of indusia (or not), plant size, mean leaf area, plant structure (rhizome, short or tall trunk), epiphytic (or not). Taxa were assigned to one of three structural types, climbing or creeping rhizomes, erect rhizome or short trunk (less than $1.5 \mathrm{~m}$ ), and tall trunk (greater than $1.5 \mathrm{~m}$ ). A typical minimum and maximum measurement for stipe length, lamina length and width and pinnae length and width were recorded for all

Table 1. Hypothesised predictions of variable effects on range sizes and their effects and significance (Sig.) or non-significance (NS) in the models for both native and introduced fern species, and for introduced species only. Model results were either in line with hypothesised effects $(\checkmark)$ or not $(\mathbf{x}) ;+$ indicates that the non-significant trend was in line with hypothesised effects. Hypothesised predictions without citations are from this paper.

\begin{tabular}{llll}
\hline Variable $\quad$ Prediction and rationale & Effect & Sig.
\end{tabular}

\section{Model with both native and introduced fern species}

Trait variables

Epiphytic

Epiphytic species will have larger range sizes than non-epiphytic species because of advantage of height for wind dispersal of spores (Tryon 1986). $\begin{array}{ll}\text { Rhizome or trunk type } & \begin{array}{l}\text { Species with tall woody trunks (i.e. tree ferns) will have larger range sizes than those without because of } \\ \text { the advantage of height for wind dispersal of spores (Tryon 1986). }\end{array}\end{array}$

Plant size

Mean lamina area Larger plants will have larger range sizes than smaller plants. Taller plants have both competitive and dispersal advantages over smaller plants due to height and more spores produced (Tryon 1986). Species with larger lamina area will have larger range sizes than those with smaller lamina area. Larger lamina area means larger photosynthetic surface and competitive advantage, by capturing more light, shading out competitors and potentially more area for spores (Tryon 1986).

Dimorphism Species with dimorphic fronds will have larger range sizes those with monomorphic fronds. Species with separate fertile fronds are more adaptable in resource partitioning in response to environmental conditions. This could give a competitive advantage (Page 2002).

Heterospory

Homosporous species will have larger range sizes than heterosporous species because they may be able to self-fertilise and therefore have an advantage in colonising new patches of habitat (Page 2002).

Indusium Species with indusia will have larger range sizes than those without indusia, as they have their spores protected from heavy rain and strong wind until ripe and the plant is ready to release them, ensuring their reproductive effort is not wasted.

Spore colour Species with green spores will have smaller range sizes that those with brown spores. Species with green spores have a shorter time frame in which to germinate (Lloyd \& Klekowski 1970) so it is more difficult to disperse widely.

Polyploidy Polyploid species will have larger range sizes than non-polyploid species. Polyploid species may be better able to adapt to a wider range of environmental conditions (Marchant et al. 2016, Pandit et al. 2011).

Habitat variables Habitat specialists

Species that are habitat specialists will have smaller range sizes than generalist species because their establishment and distributions are constrained by availability of suitable habitat (Peck et al. 1990; Gaston 1994).

Forest habitats $\quad$ Forest fern species will have larger ranges than species that only occur in other habitats. Species which prefer montane forest habitats currently have a large potential area to inhabit in New Zealand.

Open habitats Species which live in open habitats will have larger range sizes than those that do not. Species which live in open habitats have fewer physical obstacles to spore dispersal and therefore have an advantage for long distance dispersal (Tryon 1986). Also, species which live in open habitats may be better colonisers, adapted to exploiting disturbed areas, and have a lot of scope in agricultural landscapes which dominate NZ today.

Terrestrial Terrestrial species will have larger range sizes than non-terrestrial species. Terrestrial species have more potential habitat available than non- terrestrial species.

Rupestral Rupestral species will have smaller range sizes than non-rupestral species. Rupestral species are limited by the limited availability of their habitat requirements.

Distribution variables

Altitudinal zones

Species occurring in more altitudinal zones will have larger range sizes, because they have wider environmental tolerances.

Global regions

Species occurring in more global regions with will have larger range sizes than species that occur in fewer regions. Species with wide global distributions are likely to be well-dispersed generalists with wider distributions within New Zealand.

Biostatus

Introduced

Introduced species will have smaller range sizes than native species because they have only arrived within the last 200 years and have had less time to reach their maximum distribution. 
Table 1. Continued.

\begin{tabular}{ll}
\hline Variable & Prediction and rationale \\
\hline Endemic & $\begin{array}{l}\text { Endemic species will have larger range sizes than introduced species Endemic species have evolved in } \\
\text { New Zealand, are well adapted to this environment, and have had time to maximise their distributions. }\end{array}$ \\
Model results for introduced species only & Sig. \\
Global regions & $\begin{array}{l}\text { Species occurring in more global regions with will have larger range sizes than species that occur in } \\
\text { fewer regions. Introduced species with wide global distributions are likely to be well-dispersed generalists } \\
\text { with wider distributions within New Zealand. }\end{array}$ \\
Years since naturalised & $\begin{array}{l}\text { Introduced species that naturalised earlier will have larger range sizes than those that naturalised later. } \\
\text { Species that have been naturalised for longer have had a longer time to spread. }\end{array}$ \\
\hline
\end{tabular}

species for which this information was available. A plant size variable was calculated by adding the maximum stipe length and maximum lamina length. In some cases, where no stipe is present, just the maximum lamina length was used. An estimate of lamina area was calculated as the area of an oval:

mean lamina area $=\pi\left(\frac{0.5 \times\left(\mathrm{L}_{\max }+\mathrm{L}_{\min }\right)}{2}\right)\left(\frac{0.5 \times\left(\mathrm{W}_{\max }+\mathrm{W}_{\min }\right)}{2}\right)$

where $L$ is the lamina length and $W$ is the lamina width. Ferns were classified as either monomorphic if the sterile and fertile fronds were similar in appearance, or dimorphic if they differed (Jones 1987; Sharpe \& Mehltreter 2010). Most ferns have brown spores but some have green, chlorophyllous spores, therefore the colour was recorded as well as the presence or absence of indusia (protective flaps over the spore bearing structures; Jones, 1987). Information regarding spore colour was sourced from Lloyd and Klekowski (1970). The heterosporous or homosporous status of each species was taken from Smith et al. (2006). Data about polyploidy were compiled by comparing reference lists of chromosome numbers (Kramer \& Green 1990; Smith et al. 2006) with lists of observed chromosome numbers (Dawson et al. 2000; Dawson 2008).

Ferns were classified according to their habitat preferences following Brownsey \& Smith-Dodsworth (2000), Flora of North America Editorial Committee (1993), and eFloras (2014) by scoring each species as to whether it was terrestrial, epiphytic, rupestral, or none of these, and whether it was known to preferentially occur in forest or open habitats. Further, species were classified as habitat specialists if they are specialised in one of the following ways: (1) species which occur in coastal environments only, (2) those occurring predominantly in thermally active environments, (3) those only in base-rich substrates, such as limestone outcrops, (4) those that live only in water, i.e. aquatic species, (5) those which grow in hot rock habitats (dry, sunny rocky areas in full sun, excluding limestone), and (6) those only in gumland soils (sites which were previously kauri forests, characterised by infertile, acidic soils). Species which did not prefer any of these six habitats were recorded as habitat generalists. There is little host-specificity in the New Zealand fern flora. Trichomanes venosum usually occurs on the trunks of a subset of the tree fern species. Tmesipteris elongata, T. horomaka, T. lanceolata, and $T$. sigmatifolia are also usually found on tree ferns, and for some of these Tmesipteris species, the specificity is getting close to absolute and only on a subset of the tree fern species. The tree ferns themselves are widespread.

Hymenophyllum malingii mainly (but not exclusively) grows on Libocedrus bidwillii. It is unlikely that these patterns for a few species would affect species' range size patterns at the level of the New Zealand flora, so host specificity was not included as a variable.
Distribution data included the number of altitudinal zones (coastal, lowland, montane, subalpine, and alpine) and the number of global regions each species occurred in, which may reflect the environmental tolerances and dispersal abilities of species, respectively. For both introduced species and native species, the other parts of the world where each species occurred were recorded and included both current distributions and native range. Global locations were clustered into seven regions: Australia, the Pacific (excluding New Zealand), Africa, North America, South and Central America, Asia and Europe. A coarse measure of global distribution was calculated by summing the occurrence of each species across the seven regions. New Zealand endemic species were assigned a global distribution value of zero. For introduced species, the number of years since naturalisation was recorded (New Zealand Plant Conservation website http://www.nzpcn.org.nz/) as 2014 minus the year naturalised.

Biostatus data were collated by classifying each species as either endemic, native but not endemic, or introduced. The conservation status of each species in New Zealand was recorded using the New Zealand Threat Classification Series (de Lange et al. 2013).

A phylogeny for all 212 species was assembled using Mesquite (Maddison \& Maddison 2015), based on previous phylogenetic analyses of DNA sequences. Relationships among families and genera were determined using Pryer et al. (2004) and Schuettpelz \& Pryer (2007). Additional sources were used to determine relationships among genera (Wikstrom \& Kenrick 2000; Perrie et al. 2003; 2010; 2012; 2014; Korall et al. 2006; Schneider et al. 2006; Ebihara et al. 2007; Bouma et al. 2010; Hennequin et al. 2010; Lehtonen et al. 2010; He \& Zhang 2012; Perrie \& Parris 2012; Labiak et al. 2014; Brownsey et al. 2013; Ohlsen et al. 2015). Known allopolyploids were systematically linked with their maternal (chloroplast) parent.

\section{Data analysis}

Variation in range measures (ecological districts range area, latitudinal maximum, midpoint, minimum and extent) for the taxa that occurred on the mainland $(\mathrm{n}=212)$ was visualised and compared graphically across taxa and biostatus groups. We used generalised linear mixed-effects models to quantify the relationships between species' range sizes and the measured trait variables while accounting for phylogenetic non-independence of species by including genus and family as random effects in the models. Generalised linear mixed-effect modelling has the advantage over phylogenetic least squares regression of allowing an estimate of variance explained by both the fixed and random effects to be estimated (Nakagawa \& Schielzeth 2013). Pearson's correlations were used to investigate correlations among traits; only uncorrelated sets of traits were included in models explaining variation in species' range sizes. 
Two sets of mixed-effects models were constructed, each using a different subset of the data. First, a model set was constructed for the 165 species for which a full dataset of traits and other characteristics could be obtained. This model set consisted of the full model containing all variables, an intercept-only model (to allow us to estimate the overall importance of our variables), a 'trait' model (including heterospory (aquatic ferns), epiphytic, rhizome/trunk structure, plant size, dimorphism, spore colour, indusium, mean leaf area, polyploidy), a 'habitat' model (including specialist or generalist, terrestrial, rupestral, forest, open), a 'distribution' model (including number of altitudinal zones occupied, number of global regions occupied) and a 'biostatus' model (whether species were endemic, native but not endemic, or introduced). Taxonomic family and genus were both included as random effect terms. An additional model set, constructed in the same manner, but using 212 species for species with values for all variables except polyploidy, plant size and mean leaf area, gave very similar results to the model for the 165 species and so is not discussed further here (Appendix S3). We used the phylogenetic topology to create an ultrametric tree by computing branch lengths using Grafen's (1989) method. This phylogeny was used to estimate the degree to which species' range sizes were correlated with phylogeny for the full model by using weighted generalised least squares modelling to estimate Pagel's lambda for each of the model sets above (excluding genus and family). In each case, we compared a full model with lambda set to zero, which assumed no influence of evolution on range size, with a second model with lambda set to one, which assumed Brownian motion evolution, given the tree (Symonds \& Blomberg 2014).

Afinal model set using the 41 introduced species, including the 32 "casual" species, was constructed from only two variables: the number of years since naturalisation and the number of global regions occupied. This, and models containing each variable separately, were compared to an intercept-only model. Data for casual species were incomplete, so only two variables were tested. Due to the low sample size, only taxonomic family was used as a random effect.

For each of the two model sets, a full model containing all trait and characteristic data was constructed and compared to an intercept-only model. In each case, model averaging of the entire set of models was used to visualise the predicted effects of each variable (Symonds \& Moussalli2011; Mazerolle 2015). Each model was weighted according to its Akaike weight in the model averaging process, so the maximum amount of information was retained from each model, but in proportion to how useful each model was deemed to be by the previous AICc comparison process (Burnham \& Anderson 2002). The modelled effects of trait and characteristic variables are graphically presented as predicted values.

All data analyses were conducted in $\mathrm{R}$ version 3.1 .2 ( $\mathrm{R}$ Core Team 2014); generalized linear mixed effects models were conducted using the package 'Ime4' (Bates et al. 2014) and compared with the packages 'AICcmodavg' (Mazerolle 2015) and 'MuMIn' (Bartoń 2015); generalized least squares models were conducted using the package 'nlme' (Pinheiro et al.2014), and phylogenetic tree data were manipulated using the package 'ape' version 3.3 (Paradis et al. 2004).

\section{Results}

\section{Patterns in geographic range size}

The three most common species with range sizes greater than $13000 \mathrm{~km}^{2}$ were all native: Asplenium flaccidum, Asplenium hookerianum and Polystichum vestitum; of these, only $P$. vestitum is endemic. The five most narrowly-distributed species (excluding 'casuals') with range sizes less than $1000 \mathrm{~km}^{2}$ were also all native: Macrothelypteris torresiana, Notogrammitis angustifolia subsp. angustifolia, Sticherus tener, Sticherus urceolatus, Tmesipteris horomaka, and of these, only $T$. horomaka is endemic.

Most species (c. $70 \%$ ) had small range sizes of less than $75000 \mathrm{~km}^{2}$, although range sizes were not strongly rightskewed; about one-third of species had ranges greater than $75000 \mathrm{~km}^{2}$ showing that a core group of species were fairly widely distributed throughout New Zealand (Fig. 1a). Ranked species' range sizes similarly showed that very few species were widespread, with ranges greater than $100000 \mathrm{~km}^{2}$ (Fig. 1b); these patterns were unrelated to the extent of their global distributions (Appendix S4). Comparison of native and introduced species showed that the majority of introduced species were relatively narrowly distributed in New Zealand; introduced species, including most of the 'casuals', comprised $60 \%$ of the species with range sizes under $10000 \mathrm{~km}^{2}$ (Fig. 1b). In contrast, non-endemic native species and endemic species varied widely in their range sizes, and these groups contained substantially more species $(\mathrm{n}=73)$ with range sizes greater than $75000 \mathrm{~km}^{2}$ (Fig. 1b); of these, 52\% were endemics and the remainder were non-endemic, native species.

Latitudinal extent data showed that more species were relatively widely distributed across latitudes than narrowly, and that latitudinal extent was strongly related to range size (Fig. 2a). Most species had far southern range limit (Fig. 2b), range midpoints near to the centre of New Zealand: -40.85 degrees latitude (Fig. 2c), and a far northern range limit (Fig. 2d). Introduced species were the exception to these patterns, with many being limited to northern latitudes (Figs $2 \mathrm{a}-\mathrm{d}$ ).

Of the 24 native species with range sizes of less than $10000 \mathrm{~km}^{2}$, nine were categorised as habitat specialists $(38 \%$ specialists, compared to specialists comprising only $12 \%$ of the total number of species), and all but four species were on the threatened species list with ratings from "At risk, naturally uncommon" to "Threatened, nationally critical". On average, native species of conservation concern had substantially smaller range sizes than non-threatened species; the mean range size ( \pm one standard deviation) of species of conservation concern was $14627 \pm 13416$ compared to that of non-threatened species $=72288 \pm 33$ 627; (see Appendix S1 for the list of species and their current conservation status, and Appendix S5 for a comparison of range size between species of conservation concern and non-threatened; range size is one of the criteria for determining rarity and threat status).

\section{Factors correlated with range size}

Mixed-effects models for all fern species for which we had trait and other characteristics $(n=165)$ showed that four variables were important in predicting differences in range size measured as area of ecological districts occupied (Tables 1-3): (1) species that were epiphytic had larger range sizes than those that were not epiphytic (see model-averaged predictions in Fig. 3a), (2) habitat specialists (in coastal environments, thermal environments, base rich substrates, aquatic habitats or 
a.

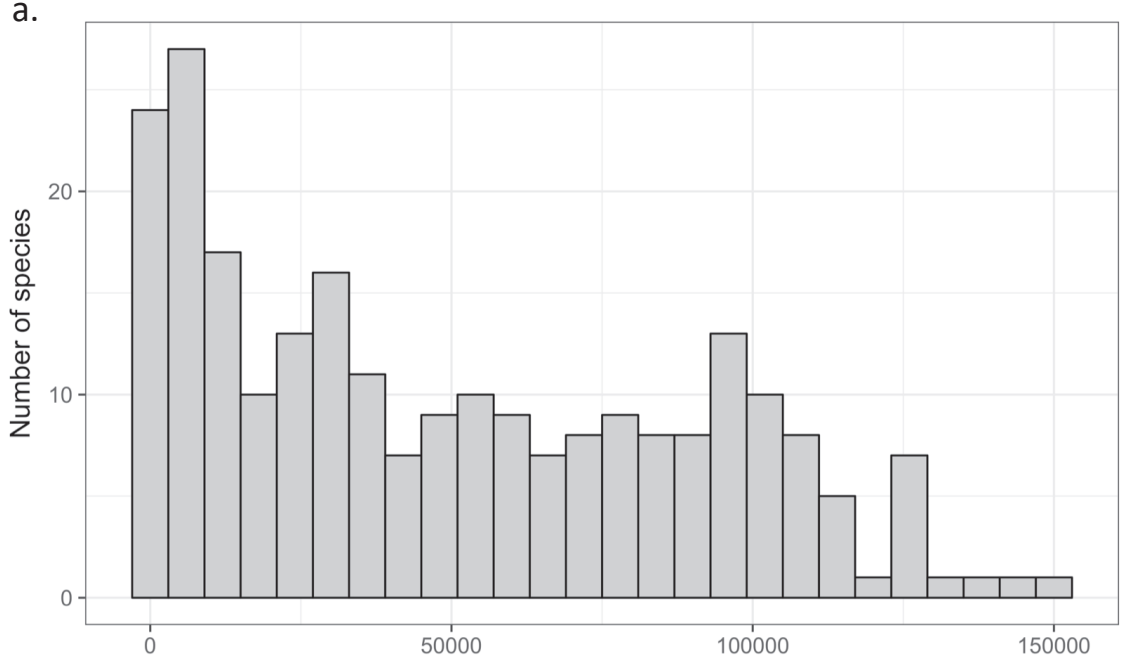

b.

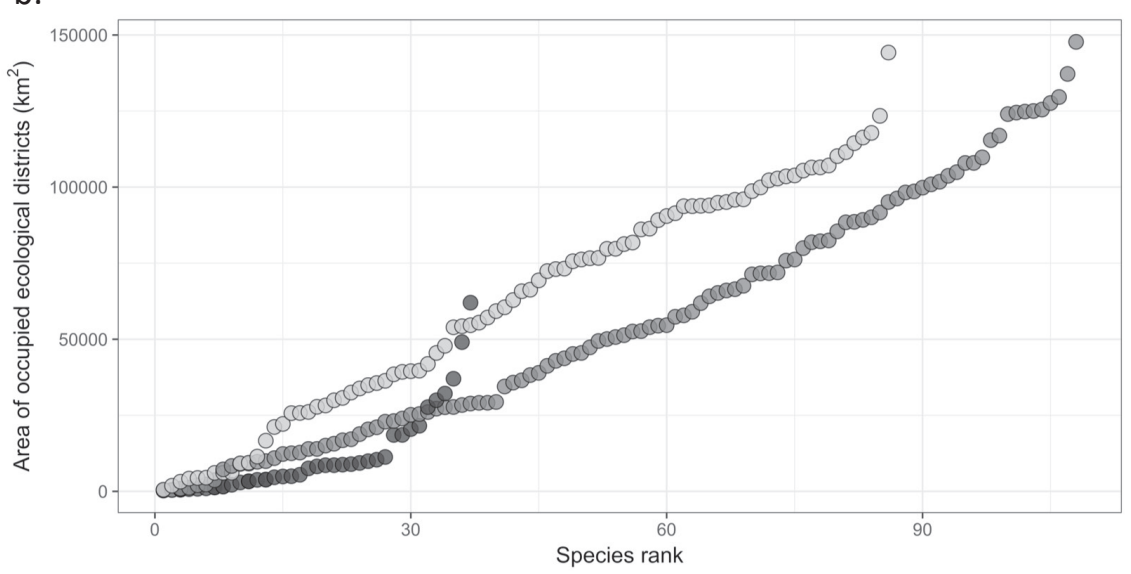

Figure 1. Range sizes of all fern species occurring on the main islands of New Zealand $(n=254)$, calculated using area of ecological districts occupied and range polygons shown as (a) frequency histograms and (b) ranks from smallest to largest range size. The number of species in each biostatus category was 50 introduced, including casuals (black), 112 native but not endemic (medium grey) and 92 endemic (light grey).

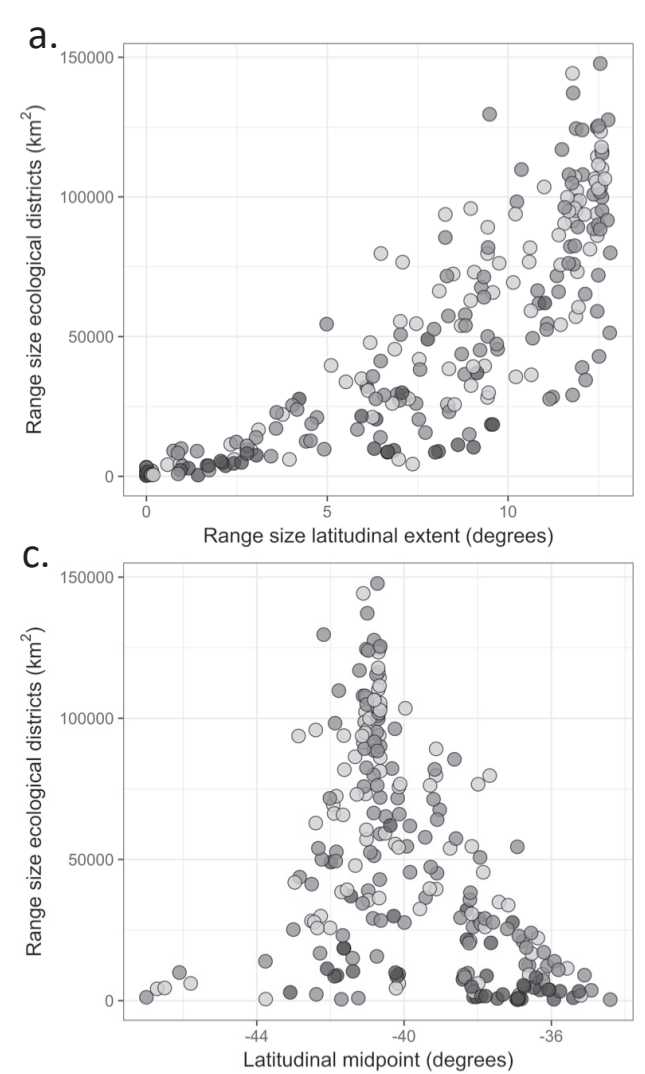

b.

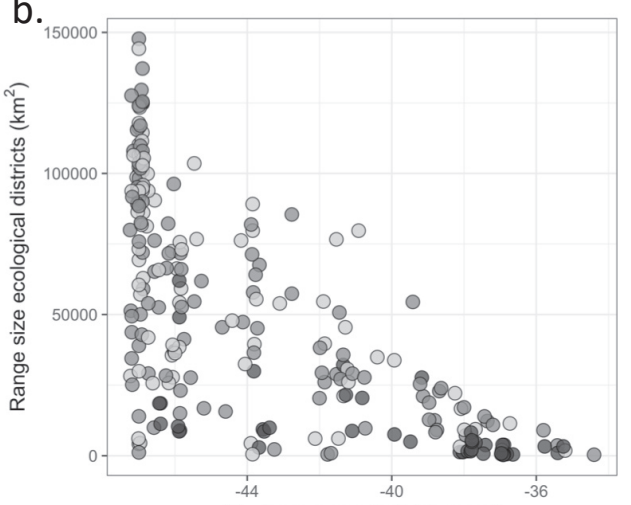

d.

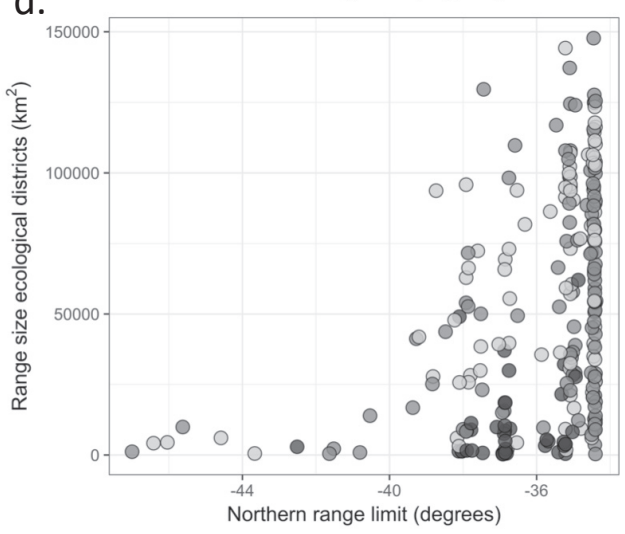

Figure 2. Different measures of range size for all fern species occurring on the three main islands of New Zealand $(\mathrm{n}=254)$. (a) Relationship between range size, as measured by the area of ecological districts occupied, and latitudinal range extent (degrees; southern range limit minus the northern range limit). Relationships between range size (as area of ecological districts occupied) for all fern species occurring on the main islands of New Zealand $(n=241)$ and their latitudinal range characteristics in degrees: (b) Southern range limit, (c) Latitudinal midpoint, and (d) Northern range limit (note that more negative latitudes are further from the equator in the Southern Hemisphere). Black circles represent introduced species, mid-grey circles represent native, but not endemic species and light grey circles represent endemic species. 
a.

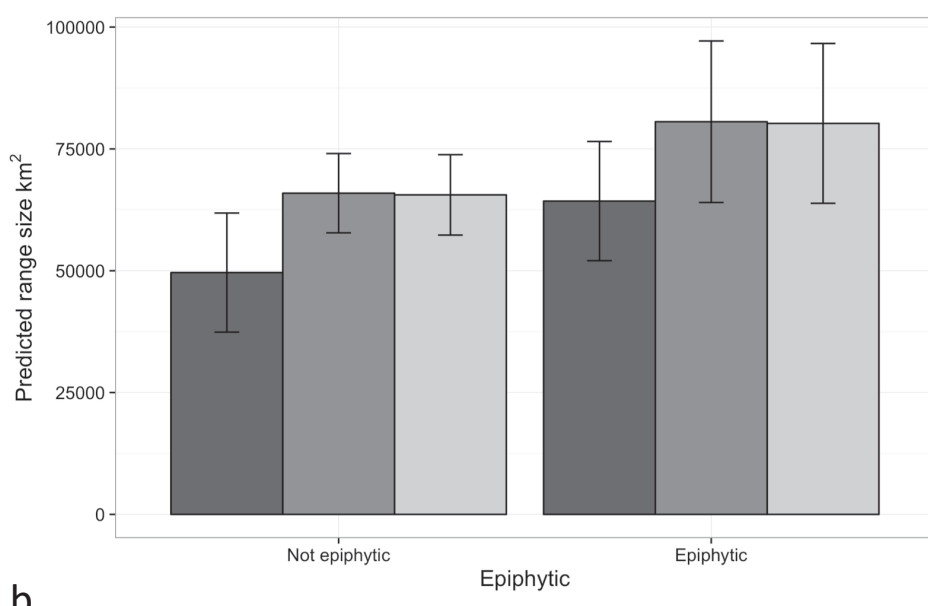

b.

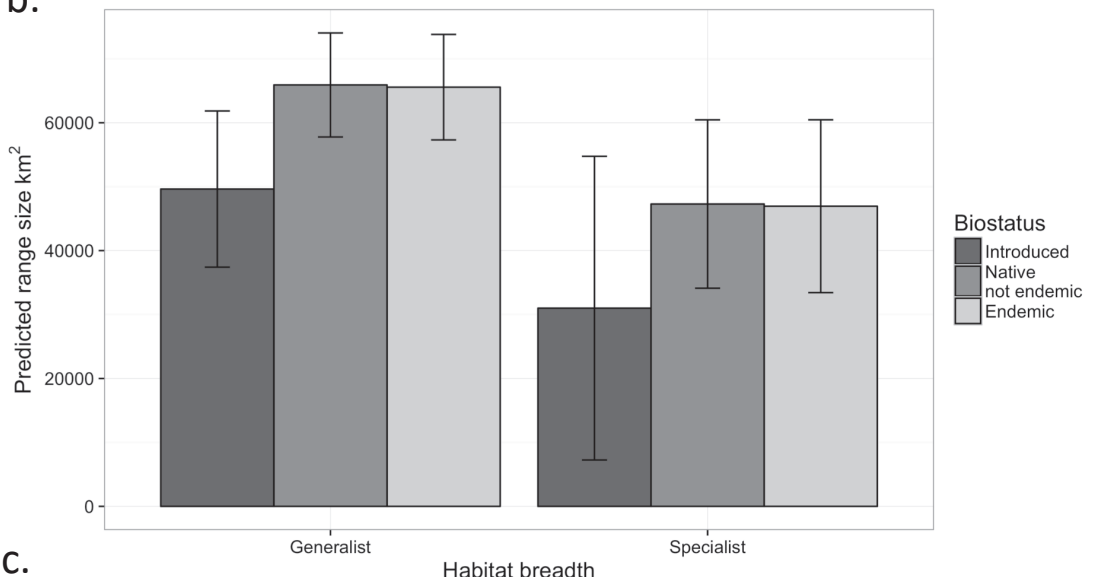

C.

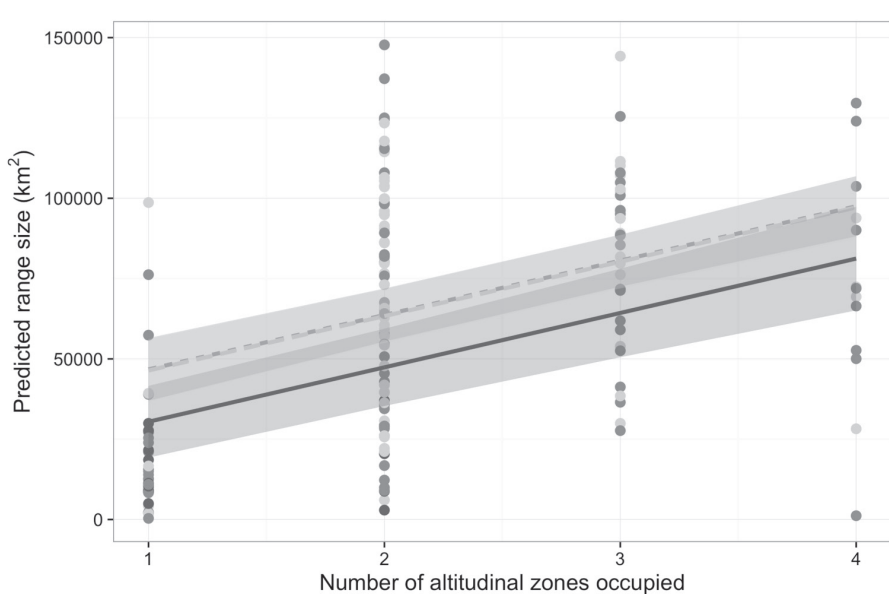

Figure 3. Model average predictions and their standard errors representing the effects of biostatus and (a) whether epiphytic (or not), (b) habitat specialist or generalist, and (c) number of altitudinal zones occupied (observed data are shown as points) on range size (area of ecological districts occupied) for 165 New Zealand fern species. gumland soils) had smaller range sizes than generalists (Fig. $3 \mathrm{~b}),(3)$ introduced species had smaller range sizes than either native but not endemic species or endemic species (Figs 3a,b), and (4) species that occupied more altitudinal zones (coastal, lowland, montane, subalpine, and alpine) had larger range sizes than those with more restricted altitudinal distributions (Fig. 3c). Azolla rubra, a widespread native aquatic fern, was the only habitat specialist with a very large range. Other variables included in the models did not predict differences in range size (Appendix S6).

For introduced species $(n=41)$, those that had been naturalised for longer had larger range sizes, as did those that occupied a greater number of global regions (Table 2, Fig. 4). The five species which had been naturalised the longest were
Cystopteris fragilis, Polystichum proliferum, Polystichum setiferum, Pteris cretica, and Osmunda regalis, and the introduced species with largest range sizes were Selaginella kraussiana and Equisetum arvense, followed by Dryopteris filix-mas and Adiantum raddianum.

\section{Importance of phylogenetic effects in determining range size}

Despite median range sizes differing substantially among genera and families (Fig. 5), only a small proportion of variation in range size was accounted for by genus $\left(\mathrm{R}^{2}{ }_{\mathrm{adj}}=\right.$ $6 \%)$ and family $\left(\mathrm{R}_{\text {adj }}^{2}=6 \%\right)$ in linear models with either genus or family as a fixed effect, and neither was a significant term in the model (Table 2). The estimate of Pagel's Lambda from 
Table 2. Linear mixed effects model AICc model comparison statistics showing the relationships between (a) range sizes and species' traits, habitat variables, distribution variables and biostatus for 165 species for which all variables were recorded and (b) range sizes of introduced (including casual) species to the number of global regions ('Global') and the years since naturalisation ('YrsNat'). In each case, all variables in the model sets were combined in a 'Full' model and compared to an 'Intercept-only' model. See Table 1 for further details of the models. In each model set, change in AICc ( $\triangle \mathrm{AICc})$ relative to the top model and the probability that each model was the top model (AICc weights; AICcWt) were calculated in comparison to all other models in the set. The number of model parameters $(\mathrm{K})$, the log likelihood of the model fitting the data better than the other models (Log Lik.), the variance explained by the fixed effects alone $\left(\mathrm{R}^{2}\right.$ fixed) and the fixed and random effects combined ( $\mathrm{R}^{2}$ total) are given. For (a), the evidence ratio between the "Full" model and the "Distribution" model was 2.13, meaning that the "Full" model is 2.13 times more likely to be the best fit model in the model set. For (b), the evidence ratio was 66.5 .

\begin{tabular}{|c|c|c|c|c|c|c|c|}
\hline Model & $\mathrm{K}$ & $\mathrm{AICc}$ & $\triangle \mathrm{AICc}$ & $\mathrm{AICcWt}$ & Log Lik. & $\mathrm{R}^{2}$ fixed & $\mathrm{R}^{2}$ total \\
\hline \multicolumn{8}{|c|}{ a. Native and introduced species $(n=165)$} \\
\hline Full & 23 & 3909.06 & 0.00 & 0.68 & -1927.61 & 0.44 & 0.44 \\
\hline Distribution & 6 & 3910.57 & 1.51 & 0.32 & -1949.02 & 0.28 & 0.28 \\
\hline Habitat & 10 & 3932.08 & 23.02 & 0.00 & -1955.32 & 0.22 & 0.28 \\
\hline Biostatus & 6 & 3937.76 & 28.70 & 0.00 & -1962.61 & 0.14 & 0.16 \\
\hline Intercept-only & 4 & 3957.05 & 47.99 & 0.00 & -1974.40 & 0.00 & 0.06 \\
\hline Trait & 14 & 3962.37 & 53.32 & 0.00 & -1965.79 & 0.11 & 0.11 \\
\hline \multicolumn{8}{|c|}{ b. Introduced species $(n=41)$} \\
\hline Full & 5 & 130.74 & 0.00 & 0.98 & -59.52 & 0.48 & 0.48 \\
\hline YrsNat & 4 & 139.14 & 8.39 & 0.01 & -65.01 & 0.32 & 0.32 \\
\hline Global & 4 & 140.70 & 9.95 & 0.01 & -65.79 & 0.31 & 0.40 \\
\hline Intercept-only & 3 & 152.24 & 21.49 & 0.00 & -72.79 & 0.00 & 0.00 \\
\hline
\end{tabular}

a.

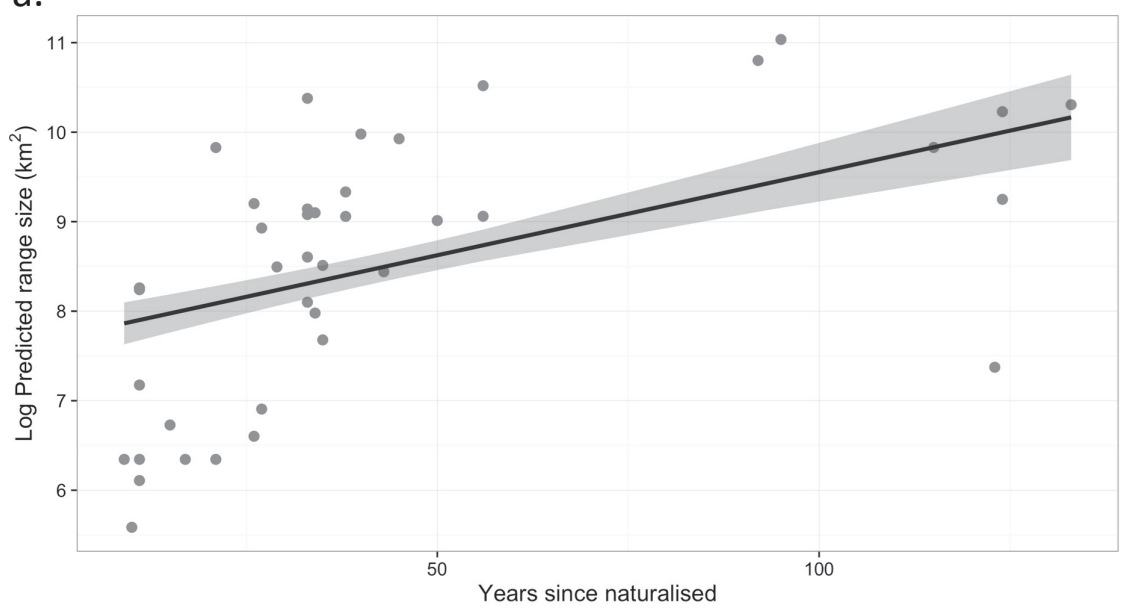

b.

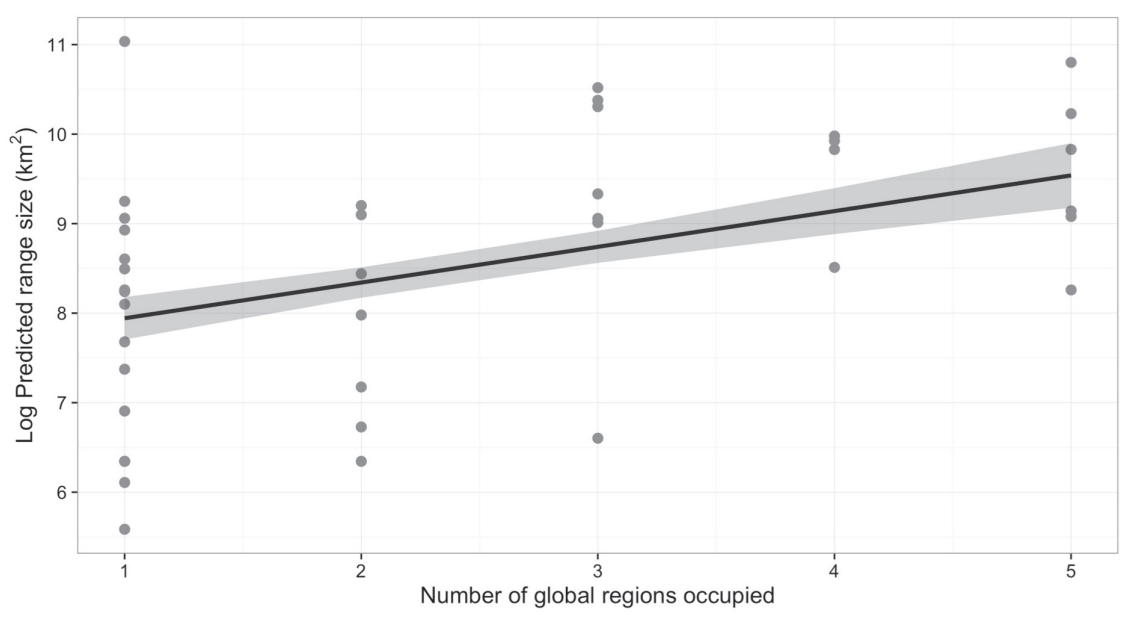

Figure 4. Model average predictions and their standard errors representing the effects of (a) years since naturalisation and (b) number of global regions occupied on range size (area of ecological districts occupied) for 41 fern species introduced to New Zealand. The coefficient estimates (standard error) values from the "Full" model were $0.66(0.17)$ for year since naturalisation and $0.59(0.17)$ for the number of global regions occupied; both are considered significant because an interval of two standard errors from these estimates did not overlap zero. Observed data are shown as points. 
Table 3. Coefficient estimates and their standard errors from the set of linear mixed effects models relating fern range sizes $(n=165)$ to species' traits (heterospory (aquatic ferns), epiphytic, trunk structure, plant size, dimorphism, spore colour, indusium, mean leafarea, polyploidy), habitat variables (specialist or generalist, terrestrial, rupestral, forest, open), distribution variables (number of altitudinal zones occupied, number of global regions occupied), and biostatus (endemic, native but not endemic, introduced). The "Full" model explained 44\% of the total variance in species' range sizes. Variables for which an interval of two standard errors from the estimate does not overlap zero are considered significant (bold).

\begin{tabular}{lrr}
\hline Variable & Estimate & Standard error \\
\hline Heterospory & 30522.1 & 18300.8 \\
Specialist vs. generalist habitat preference & $-\mathbf{2 7 3 6 5 . 0}$ & $\mathbf{8 5 2 6 . 7}$ \\
Biostatus - native but not endemic vs. introduced & $\mathbf{2 3 9 2 8 . 0}$ & $\mathbf{9 3 9 1 . 0}$ \\
Biostatus - endemic vs. introduced & $\mathbf{2 3 4 2 0 . 4}$ & $\mathbf{1 1 3 3 9 . 0}$ \\
Epiphytic & $\mathbf{2 1 5 4 9 . 6}$ & $\mathbf{7 5 6 7 . 3}$ \\
Number of altitudinal zones occupied & $\mathbf{1 3 7 3 7 . 9}$ & $\mathbf{2 7 1 3 . 8}$ \\
Terrestrial & 12418.8 & 8118.3 \\
Rhizome/Trunk structure - creeping vs. tall & -12307.9 & 18457.4 \\
Rhizome/Trunk structure - short vs. tall & -9671.5 & 18587.9 \\
Plant size & 7942.8 & 4095.7 \\
Dimorphic fronds & 7504.3 & 8079.7 \\
Rupestral & -7231.9 & 7942.2 \\
Forest habitat & 6387.1 & 6366.7 \\
Spore colour - green & -5800.7 & 8626.9 \\
Open habitat & -2637.6 & 5363.4 \\
Indusium present & -2065.8 & 5983.4 \\
Number of global regions occupied & -3744.2 & 3572.8 \\
Rhizome/Trunk structure - creeping vs. short & 2636.4 & 5305.2 \\
Mean leaf area & -1337.6 & 4753.5 \\
Polyploid & -846.1 & 6209.9 \\
Biostatus - endemic vs. native but not introduced & -507.6 & 6359.2 \\
\hline
\end{tabular}

a.

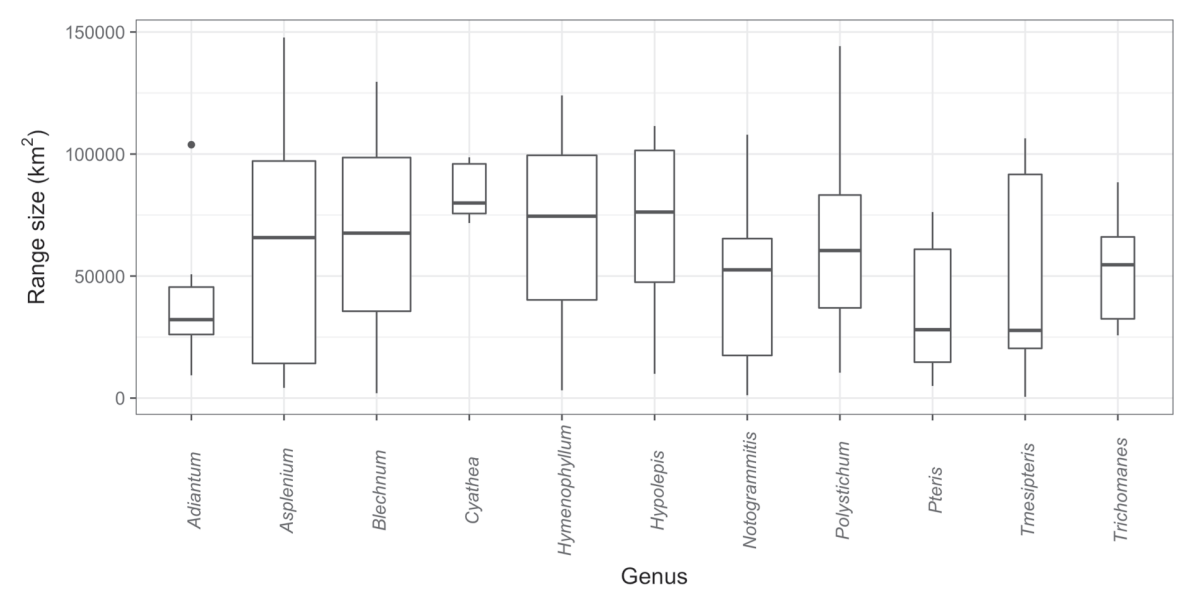

b.

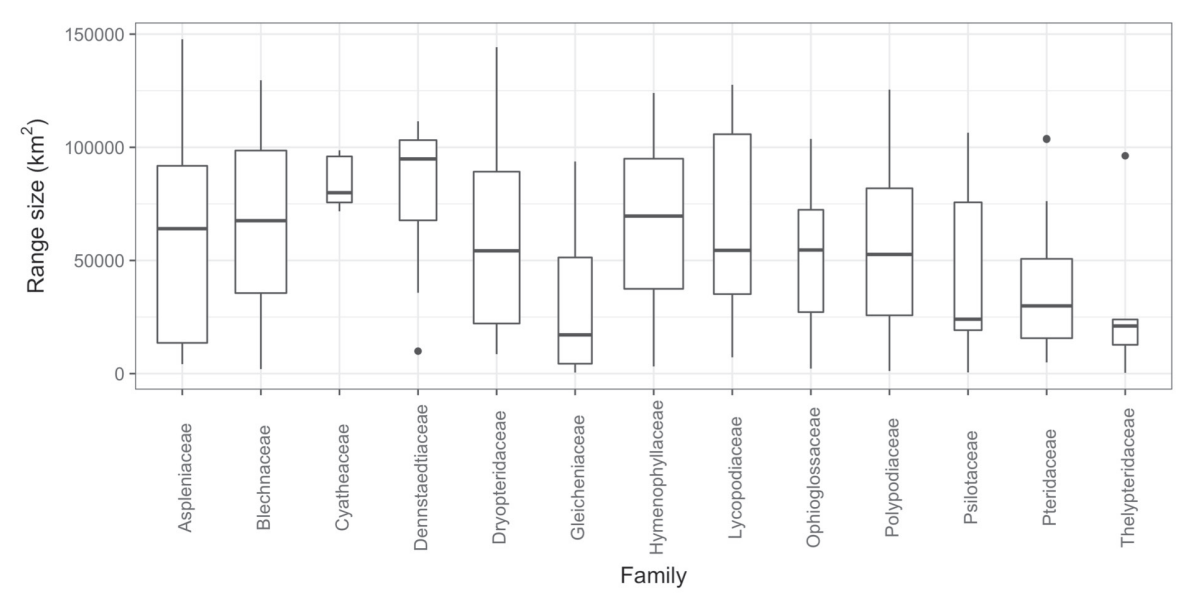

Figure 5. Boxplots showing the distribution of range sizes calculated as the area of ecological districts occupied for (a) species in the eleven genera with five or more species, (b) species in the thirteen families with five or more species. The black line within the box represents the median range size, the box is the interquartile ranges and the whiskers are 1.5 times the interquartile range. Box widths are proportional to the number of species in each taxon. 
a generalized least squares model $(\mathrm{n}=165)$ containing all fixed effects was $0.04(-0.28,0.36=95 \%$ confidence interval, which includes zero). Likelihood ratio tests comparing the fit of generalized least squares models setting Pagel's lambda to zero (assuming no influence of phylogeny on range size) and one (assuming Brownian motion in evolution, given the tree) showed that the model excluding phylogeny fitted better. These results suggest that phylogeny was not significantly related to the range sizes of ferns.

\section{Discussion}

Patterns in New Zealand fern range size are consistent with those of other taxonomic groups (Rabinowitz 1981, Gaston 1996, Gaston et al. 1998, Morin \& Lechowicz 2011). More species have narrow ranges than are widespread, range sizes decrease at latitudes closer to the equator and species' traits and habitat preferences are correlated with range size: species with larger ranges are more likely to be native, have an epiphytic growth habit, be able to occupy a wider altitudinal range, and/ or are not a habitat specialist. We discuss these results in the context of rarity classification, spatial patterns in range size, and the implications of biostatus and habitat preferences for future changes in the New Zealand fern flora.

We observed a greater number of range-limited than widespread species; however, a substantial proportion of native species had relatively large range sizes, of greater than 75000 $\mathrm{km}^{2}$ (Fig. 1). This suggests that a large proportion of species are not limited by their dispersal ability (Brownsey 2001; McGlone et al. 2001). The larger proportion of species with narrower ranges, the 'rare' species, may be thought to be at higher risk of extinction (Di Marco \& Santini 2015). However, we have investigated only two of the three characteristics (range size and habitat specialisation, but not population density) with which Rabinowitz (1981) constructed her classification of rarity, so we can only classify rarity patterns for New Zealand ferns in a simpler matrix of four types (Table 4). The upper left quadrant of Table 4 contains widespread species, of which most are considered common; $22 \%$ of species occur throughout the three main islands (Brownsey 2001). The upper right quadrant contains species which are not habitat specialists, but in New Zealand, their ranges are restricted to northern latitudes by temperature tolerance. Some of these species have widespread tropical distributions. Others are introduced species with small ranges, probably due to their recent introduction, rather than habitat specificity. The lower left quadrant contains those few species that are relatively widespread in spite of their habitat specificity (likely due to their specific habitat being widespread), and the lower right quadrant contains those species with very specific habitat requirements and restricted ranges (likely due to their specific habitat being narrowly distributed).

The effect of geometric constraints due to the shape of New Zealand (Colwell \& Hurtt 1994, Colwell \& Lees 2000) is a strong determinant of range size for these ferns, a result consistent with McGlone et al. (2010) for tree ferns. Many native and endemic species have large geographic ranges that are only constrained by either the terrestrial southern or northern limit of New Zealand. These geometric constraints create a pattern partially consistent with Rapoport's rule, which predicts that species' range sizes become smaller towards the equator (Janzen 1967; Rapoport 1982; Stevens 1989). In New Zealand, latitudinal extent was strongly related to fern range size (Fig. 2a). However, fern distributions were only measured within the major islands of New Zealand, regardless of where they occurred elsewhere, so distributions necessarily end where the land meets the sea, if not before. Thus, the relationship between range size and latitude asymptotes at the latitudinal extent of New Zealand: from -47.31 to -34.38 degrees latitude (Figs $2 \mathrm{c}, \mathrm{d})$; species with midpoints further towards the northern or the southern end of New Zealand had smaller ranges (Fig. 2c). The distributions of species northern and southern latitudinal limits show that many species had large ranges extending well into the South Island, but only a few species were restricted to these southern areas (Figs 2b,d). Consequently, many species with large ranges had range latitudinal mid-points occurring near the latitudinal mid-point of New Zealand (Fig. 2c). Species with large range sizes are expected to be more geometrically constrained than those with small range sizes (Colwell \& Hurtt 1994). New Zealand has a long latitudinal spread and is relatively narrow longitudinally, so range sizes and latitudinal extent were correlated (Fig. 2a). Thus, any other mechanisms that might generate patterns consistent with Rapoport's rule are likely to be partially obscured by the strong effect of geometric constraints (Colwell \& Lees 2000). For example, there were a larger number of species with range mid-points in northern New Zealand latitudes than southern (Fig. 2c). These northern species often are ferns of tropical origin, which are restricted to the far north of New Zealand by climatic constraints (Brownsey 2001).

We identified four factors significantly correlated with range size across all New Zealand fern species: epiphytic growth habit, habitat specialisation, the number of altitudinal

Table 4. Types of rarity identified for New Zealand ferns based on their geographic range size and their habitat specificity.

\begin{tabular}{lll}
\hline \multirow{2}{*}{ Habitat specificity } & Geographic range \\
Wide & Small & \\
& $\begin{array}{l}\text { Widespread, common, native, e.g. Polystichum } \\
\text { vestitum, Blechnum penna-marina, }\end{array}$ & $\begin{array}{l}\text { Limited range, but habitat generalists, e.g. native (but not } \\
\text { endemic) tropical species confined to far North of New }\end{array}$ \\
& $\begin{array}{l}\text { Microsorum pustulatum. } \\
\text { Zealand by temperature such as Pteris comans, }\end{array}$ \\
& $\begin{array}{l}\text { Macrothelypteris torresiana. This category also includes } \\
\text { most introduced species. }\end{array}$
\end{tabular}

Narrow

Widespread, but habitat specialists, e.g. Asplenium lyallii (endemic), which grows in base-rich environments and Azolla rubra, a native aquatic fern.
Very restricted ranges and habitat specialists, e.g. Asplenium cimmeriorum, limestone cave entrances; Dicranopteris linearis geothermal areas; Pleurosorus rutifolius hot rocks. 
zones inhabited and biostatus. Native species had significantly larger range sizes than introduced species. Fern species introduced to New Zealand have all arrived since European settlement, a little over 200 years ago. This contrasts with the native species, which have all had much longer periods of time in which to disperse, adapt and evolve in situ, so it is not surprising that they have larger ranges than introduced species. Three quarters of the introduced species analysed are classed as "casuals", meaning they are not considered naturalised, and these, by definition, have very small, and sometimes disjunct, ranges. There is a clear relationship between the length of time since a fern species arrived and how far it has spread, consistent with introduced species from other plant groups in New Zealand (Sullivan et al. 2004). This pattern of increasing range size over time indicates that we can expect future spread of introduced ferns. The number of global regions that an introduced species occurs in was also found to relate to range size, so it is likely that some species that are already widespread outside of New Zealand will extend their ranges within New Zealand significantly, and may become invasive, as has already occurred for Equisetum arvense, Selaginella kraussiana and Dryopteris filix-mas.

Not surprisingly, we observed that, on average, habitat specialists had significantly smaller range sizes than habitat generalists. This pattern is likely explained by the limited area of the preferred habitats of these specialist species, such as thermal zones, and limestone areas. One species that breaks that pattern is the aquatic fern, Azolla rubra, which has a relatively large range size $\left(82199 \mathrm{~km}^{2}\right)$. This species is the only nitrogen-fixing fern native to New Zealand (symbiosis with the cyanobacterium Anabaena azolae) (Peters 1977), which may increase its tolerated range of habitats. The number of altitudinal zones occupied was included in our models to represent elevational differences in fern distributions, in the absence of more precise elevation data. These altitudinal zones reflect different habitat types in that a larger elevational range indicates a broader tolerance of environmental differences (Kessler 2002), which implies generalist habitat preferences and therefore, larger expected range sizes. Ferns which grew epiphytically were more widespread than those which did not; $42 \%$ of the species with the 50 largest range sizes were epiphytic, whereas only $30 \%$ of all species were epiphytic. This result is consistent with some other studies (e.g. Bach et al. 2007) and could be because of the added height gained from their host trees creating an advantage for spore dispersal to new sites. However, Watkins et al. (2006) observed that epiphytes have larger elevational ranges, suggesting they have broader climatic tolerances than terrestrial species. In contrast to the pattern observed here, Kessler (2002) observed no relationship between epiphytic growth forms and range size in ferns in Bolivia.

The effect of phylogenetic relatedness on range size was found to be very small relative to the effects of the other variables tested. Guo et al. (2003) found indications of possible phylogenetic constraints on distributions in Japanese ferns by analysing differences between speciose genera and the Japanese fern flora as a whole. In New Zealand ferns there is considerable variation in range size distributions among taxonomic families and among genera. Almost all genera contain a few species with very small range sizes, but not all genera have species with very large range sizes. Adiantum and Lycopodiella are unusual among genera because almost all species have relatively small range sizes (except Adiantum cunninghamii). Cyathea and Lastreopsis are unusual in that both have little variation in range size among their species, and all are mid-size. However, our analysis showed the overall relationship across the 165 modelled species between phylogeny and range size of ferns was insignificant.

Species' geographic range sizes are seen as predictors of their extinction risk (Di Marco \& Santini 2015). Our research shows that a substantial portion of the fern flora appear to be habitat specialists that are consequently limited in their distributions and thus at risk from land use change, climate change effects and disturbance. These results highlight data gaps required for further research on the ecology and conservation of New Zealand ferns (also see Brock et al. 2016). More meaningful predictions of potential change in species' distributions could be made by including information on other ecological characteristics such as detailed habitat preferences, population dynamics, and response to environmental disturbances (e.g. Brock et al. 2018). Further, such data, when combined with more detailed trait data which better represent species' environmental effects and responses, such as from the leaf economic spectrum (Karst \& Lechowicz 2007) and leaf venation (Sack \& Scoffoni 2013), can be used to ask interesting questions about drivers of the spatial distributions of New Zealand ferns.

\section{Acknowledgements}

The herbaria at Te Papa, the Auckland War Memorial Museum and the Allan Herbarium at Landcare Research provided records for species which formed the basis of the spatial data in this study. The New Zealand Department of Conservation provided the ecological districts GIS layer. Thanks to Marian Dassonneville and Anais Tieche for data entry assistance and the Lincoln University Spatial Ecology Lab Group for productive discussions of this work. Funding was provided by Lincoln University (HLB) and the Freemasons University Scholarship (CFM). We are grateful to Matt McGlone, James Brock and Janice Lord for constructive comments that greatly improved this paper.

\section{References}

Arens NC 2001. Variation in performance of the tree fern Cyathea caracasana (Cyatheaceae) across a successional mosaic in an Andean cloud forest. American Journal of Botany 88: 545-551.

Bach K, Kessler M, Gradstein SR 2007. A simulation approach to determine statistical significance of species turnover peaks in a species-rich tropical cloud forest. Diversity and Distributions 13: 863-870.

Barrington DS 1993. Ecological and historical factors in fern biogeography. Journal of Biogeography 20: 275-279.

Bartoń K 2015. MuMIn: Multi-model inference. R package version 1.13.4, http://CRAN.R-project.org/ package $=$ MuMIn .

Bates D, Maechler M, Bolker B, Walker S 2014. lme4: Linear mixed-effects models using Eigen and S4. R package version 1.1-7, http://CRAN.R-project.org/package=lme4.

Bouma WLM, Ritchie P, Perrie LR 2010. Phylogeny and generic taxonomy of the New Zealand Pteridaceae ferns from chloroplast $r b c L$ DNA sequences. Australian Systematic Botany 23: 143-151. 
Breitweiser I, Brownsey PJ, Garnock-Jones PJ, Perrie LR, Wilton AD 2009. Phylum Tracheophyta: Vascular Plants. In: Gordon DP ed. The New Zealand Inventory of Biodiversity 3. Pp 411-421. Christchuch, Canterbury University Press.

Brock JM, Perry GLW, Lee WG, Burns BR 2016. Tree fern ecology in New Zealand: A model for southern temperate rainforests. Forest Ecology and Management 375: 112-126.

Brock JM, Perry GLW, Lee WG, Schwendenmann L, Burns BR 2018. Pioneer tree ferns influence community assembly in northern New Zealand forests. New Zealand Journal of Ecology 42: 1-13.

Brownsey PJ 2001. New Zealand's pteridophyte flora - plants of ancient lineage but recent arrival? Brittonia 53:284-303.

Brownsey PJ, Perrie LR 2013a. Taxonomic notes on the New Zealand flora: the status of Schizaea australis and S.fistulosa, and lectotypes in Lygodiaceae and Schizaeaceae. New Zealand Journal of Botany 51: 79-87.

Brownsey PJ, Perrie LR 2013b. Te Papa's list of New Zealand ferns and lycophytes. Wellington, Te Papa. 7 p.

Brownsey PJ, Smith-Dodsworth JC 2000. New Zealand ferns and allied plants, 2nd edn. Auckland, David Bateman. $200 \mathrm{p}$.

Brownsey PJ, Ewans R, Rance B, Walls S, Perrie LR 2013. A review of the fern genus Sticherus (Gleicheniaceae) in New Zealand with confirmation of two new species records. New Zealand Journal of Botany 51: 104-115.

Buckley HL, Freckleton RP 2010. Understanding the role of species dynamics in abundance-occupancy relationships. Journal of Ecology 98: 645-58.

Burnham K, Anderson DR 2002. Model selection and multimodel inference. A practical information-theoretic approach. 2nd edn. New York, USA, Springer. 353 p.

Colwell RK, Hurtt GC 1994. Nonbiological gradients in species richness and a spurious Rapoport effect. American Naturalist 144: 570-595.

Colwell RK, Lees DC 2000. The mid-domain effect: geometric constraints on the geography of species richness. Trends in Ecology \& Evolution 15: 70-76.

Davis MB, Shaw RG 2001. Range shifts and adaptive responses to Quaternary climate change. Science 292(5517): 673-679.

Dawson MI 2008. Index of chromosome numbers of indigenous New Zealand vascular plants. Unpublished report for Manaaki Whenua - Landcare Research.

Dawson MI, Brownsey PJ, Lovis JD 2000. Index of chromosome numbers of indigenous New Zealand pteridophytes. New Zealand Journal of Botany 38: 25-46.

de Lange PJ, Rolfe JR, Champion PD, Courtney SP, Heenan PB, Barkla JW, Cameron EK, Norton DA, Hitchmough RA2013. Conservation status of New Zealand indigenous vascular plants, 2012. New Zealand threat classification series 3. Wellington, Department of Conservation. $74 \mathrm{p}$.

Diamond E, Frame AM, Martin, RA, Buckley LB 2011. Species' traits predict phenological responses to climate change in butterflies. Ecology 92: 1005-1012.

Di Marco M, Santini L 2015. Human pressures predict species' geographic range size better than biological traits. Global Change Biology 21: 2169-2178.

Ebihara A, Iwatsuki K, Ito M, Hennequin S, Dubuisson J-Y 2007. A global molecular phylogeny of the fern genus Trichomanes (Hymenophyllaceae) with special reference to stem anatomy. Botanical Journal of the Linnean Society
155: $1-27$

eFloras 2014. Published on the internet. Missouri Botanical Garden, St. Louis, MO \& Harvard University Herbaria, Cambridge, MA http://www.efloras.org/ (accessed 14 April 2014).

Estrada A, Morales-Castilla I, Caplat P, Early R 2016. Usefulness of species traits in predicting range shifts. Trends in Ecology and Evolution 31: 190-203.

Flora of North America Editorial Committee eds 1993. Flora of North America North of Mexico. New York, Oxford University Press. 590 p.

Gaston KJ 1994. Rarity. London, Chapman \& Hall. 205 p.

Gaston KJ 1996. Species range size distributions: Patterns, mechanisms and implications. Trends in Ecology \& Evolution 11: 197-201.

Gaston KJ, Quinn RM, Blackburn TM, Eversham BC 1998. Species range-size distributions in Britain. Ecography 21: 361-370.

Grafen A 1989. The phylogenetic regression. Philosophical Transactions of the Royal Society of London. Series B, Biological Sciences 326: 119-157.

Guo Q, Kato M, Ricklefs RE 2003. Life history, diversity and distribution: a study of Japanese pteridophytes. Ecography 26: $129-138$.

He L-J, Zhang X-C 2012. Exploring generic delimitation within the fern family Thelypteridaceae. Molecular Phylogenetics and Evolution 65: 757-764.

Hennequin S, Ebihara A, Dubuisson J-Y, Schneider H. 2010. Chromosome number evolution in Hymenophyllum (Hymenophyllaceae), with special reference to the subgenus Hymenophyllum. Molecular Phylogenetics and Evolution 55: 47-59.

Janzen DH 1967. Why mountain passes are higher in the tropics. American Naturalist 101: 233-249.

Jones DL 1987. Encyclopaedia of Ferns. Portland, Timber Press. 452 p.

Karst AL, Lechowicz MJ 2007. Are correlations among foliar traits in ferns consistent with those in the seed plants? New Phytologist 173: 306-312.

Kessler M2002. Range size and its ecological correlates among the pteridophytes of Carrasco National Park, Bolivia. Global Ecology and Biogeography 11: 89-102.

Kessler M 2010. Biogeography of ferns. In: Mehltreter K, Walker LR, Sharpe JM eds. Fern Ecology. New York, USA, Cambridge University Press. Pp. 22-60.

Korall P, Pryer KM, Metzgar JS, Schneider H, Conant DS 2006. Tree ferns: monophyletic groups and their relationships as revealed by four protein-coding plastid loci. Molecular Phylogenetics and Evolution 39: 830-845.

Kramer K, Green P, 1990. Pteridophytes and gymnosperms Vol. 1. The families and genera of vascular plants. Berlin, Springer Verlag. 404 p.

Kunin WE, Gaston KJ 1997. The biology of rarity: causes and consequences of rare-common differences. London, Chapman and Hall. 280 p.

Labiak PH, Sundue M, Rouhan G, Hanks JG, Mickel JT, Moran RC 2014. Phylogeny and historical biogeography of the lastreopsid ferns (Dryopteridaceae). American Journal of Botany 101: 1207-1228.

Lehmann A, Leathwick JR, Overton JM 2002. Assessing New Zealand fern diversity from spatial predictions of species assemblages. Biodiversity and Conservation 11: 2217-2238.

Lehtonen S, Tuomisto H, Rouhan G, Christenhusz MJM2010. 
Phylogenetics and classification of the pantropical family Lindsaeaceae. Botanical Journal of the Linnean Society 163: 305-359.

Lloyd RM, Klekowski EJ Jr. 1970. Spore germination and viability in Pteridophyta: evolutionary significance of chlorophyllous spores. Biotropica 2: 129-137.

Maddison WP, Maddison DR 2015. Mesquite: a modular system for evolutionary analysis. Version 3.03, http:// mesquiteproject.org

MarchantDB, Soltis DE, and Soltis PS 2016. Patterns of abiotic niche shifts in allopolyploids relative to their progenitors. New Phytologist 212: 708-718.

Mazerolle MJ 2015. AICcmodavg: Model selection and multimodel inference based on (Q)AIC(c). R package version 2.0-3. http://CRAN.R-project.org/ package $=$ AICcmodavg.

McEwen M 1987. Ecological regions and districts of New Zealand. 3rd edn. in four 1:500 000 map. New Zealand Biological Resources Centre Publication No. 5. Wellington, Department of Conservation. $455 \mathrm{p}$.

McGlone M 1985. Plant biogeography and the late Cenozoic history of New Zealand. New Zealand Journal of Botany 23: 723-749.

McGlone MS, Duncan RP, Heenan PB 2001. Endemism, species selection and the origin and distribution of the vascular plant flora of New Zealand. Journal of Biogeography 28:199-216.

McGlone MS, Richardson SJ, Jordan GJ 2010. Comparative biogeography of New Zealand trees: species richness, height, leaf traits and range sizes. New Zealand Journal of Ecology 34: 137-151.

Mehltreter K, Flores-Palacios A, García-Franco J 2005. Host preferences of low-trunk vascular epiphytes in a cloud forest of Veracruz, Mexico. Journal of Tropical Ecology 21: 651-660.

Morin X, Lechowicz MJ 2011. Geographical and ecological patterns of range size in North American trees. Ecography 34: $738-750$

Nagalingum NS, Knerr N, Laffan SW, González-Orozco CE, Thornhill AH, Miller JT, Mishler BD 2015. Continental scale patterns and predictors of fern richness and phylogenetic diversity. Frontiers in Genetics 6.32 p.

Nakagawa S, Schielzeth H 2013. A general and simple method for obtaining $\mathrm{R}^{2}$ from generalized linear mixed effects models. Methods in Ecology and Evolution 4: 133-142.

Nathan R 2006. Long-distance dispersal of plants. Science 313(5788): 786-788.

Ohlsen DJ, Perrie LR, Shepherd LD, Brownsey PJ, Bayly MJ 2015. Phylogeny of the fern family Aspleniaceae in Australasia and the south-west Pacific. Australian Systematic Botany 27: 355-371.

Page CN 2002. Ecological strategies in fern evolution: a neopteridological overview. Review of Palaeobotany and Palynology 119: 1-33.

Pandit MK, Pocock MJO, Kunin WE 2011. Ploidy influences rarity and invasiveness in plants. Journal of Ecology 99: 1108-1115.

Paradis E, Claude J, Strimmer K 2004. APE: analyses of phylogenetics and evolution in R language. Bioinformatics 20: 289-290.

Peck J, Peck C, Farrar D 1990. Influences of life history attributes on formation of local and distant fern populations. American Fern Journal 80: 126-142.

Perrie LR, Brownsey PJ 2012. Lastreopsis kermadecensis, a new fern species from Raoul Island in the Kermadec Islands, New Zealand, with notes on L. pacifica. New Zealand Journal of Botany 50: 29-36.

Perrie LR, Parris BS 2012. Chloroplast DNA sequences indicate the grammitid ferns (Polypodiaceae) in New Zealand belong to a single clade, Notogrammitis gen. nov. New Zealand Journal of Botany 50: 457-472.

Perrie LR, Brownsey PJ, Lovis JD 2010. Tmesipteris horomaka, a new octoploid species from Banks Peninsula. New Zealand Journal of Botany 48: 15-29.

Perrie LR, Shepherd LD, Brownsey PJ 2012. Gleichenia inclusisora, a new and uncommon tangle fern from New Zealand. New Zealand Journal of Botany 50: 401-410.

Perrie LR, Brownsey PJ, Lockhart PJ, Brown EA, Large MF 2003. Biogeography of temperate Australasian Polystichum ferns as inferred from chloroplast sequence and AFLP. Journal of Biogeography 30: 1729-1736.

Perrie LR, Shepherd LD, de Lange PJ, Batty EL, Ohlsen DJ, Bayly MJ, Brownsey PJ 2013. Hymenophyllum pluviatile, a new and uncommon fern from New Zealand. New Zealand Journal of Botany 51: 308-320.

Perrie LR, Wilson RK, Shepherd LD, Ohlsen DJ, Batty EL, Brownsey PJ, Bayly MJ 2014. Molecular phylogenetics and generic taxonomy of Blechnaceae ferns. Taxon 63: $745-758$.

Peters GA 1977. The Azolla-Anabaena azzolae symbiosis. In: Hollaender A, Burris RH, Day PR, Hardy RWF, Helinski DR, Lamborg MR, Owens L, Valentine RC eds. Genetic engineering for nitrogen fixation. Boston, Springer. Pp. 231-258.

Pinheiro J, Bates D, DebRoy S, Sarkar D and R Core Team 2014. nlme: Linear and nonlinear mixed effects models. R package version 3.1-118, http://CRAN.R-project.org/ package $=$ nlme.

PPG I 2016. A community-derived classification for extant lycophytes and ferns. Journal of Systematic Evolution 54: 563-603.

Pryer KM, Schuettpelz E, Wolf PG, Schneider H, Smith AR, Cranfill R 2004. Phylogeny and evolution of ferns (monilophytes) with a focus on the early leptosporangiate divergences. American Journal of Botany 91: 1582-1598.

R Core Team 2014. R: A language and environment for statistical computing. R Foundation for Statistical Computing, Vienna. http://www.R-project.org/ (accessed 6 August 2014).

Rabinowitz D 1981. Seven forms of rarity. In: Synge H ed. The biological aspects of rare plant conservation. Cambridge, John Wiley \& Sons, Pp. 205-218.

Ramírez-Barahona S, Luna-Vega I 2015. Geographic differentiation of tree ferns (Cyatheales) in tropical America. American Fern Journal 105:73-85.

Rapoport E 1982. Areography: geographical strategies of species. Oxford, Pergamon Press. 286 p.

Reich PB, Sendall KM, Rice K, Rich RL, Stefanski A, Hobbie SE, Montgomery RA 2015. Geographic range predicts photosynthetic and growth response to warming in cooccurring tree species. Nature Climate Change 5: 148-152.

Richard M, Bernhardt T, Bell G 2000. Environmental heterogeneity and the spatial structure of fern species diversity in one hectare of old growth forest. Ecography 23, 231-245.

Sack L, Scoffoni C 2013. Leaf venation: structure, function, development, evolution, ecology and applications in the 
past, present and future. New Phytologist 198: 983-1000.

Schneider H, Kreier H-P, Perrie LR, Brownsey PJ 2006. The relationships of Microsorum species occurring in New Zealand. New Zealand Journal of Botany 44: 121-127.

Schuettpelz E, Pryer KM 2007. Fern phylogeny inferred from 400 leptosporangiate species and three plastid genes. Taxon 56: 1037-1037.

Sharpe JM, Mehltreter K 2010. Ecological insights from fern population dynamics. In: Mehltreter K, Walker LR, Sharpe JM eds. Fern Ecology. New York, Cambridge University Press. Pp. 61-110.

Smith AR, Pryer KM, Schuettpelz E, Korall P, Schneider H, Wolf PG 2006. A classification for extant ferns. Taxon 55: 705-731.

Stevens GC 1989. The latitudinal gradient in geographical range - how so many species coexist in the tropics. American Naturalist 133: 240-256.

Sullivan J, Williams P, Cameron EK, Timmins S 2004. People and time explain the distribution of naturalised plants in New Zealand. Weed Technology 18: 1330-1333.

Symonds MRE, Blomberg SP 2014. A primer on phylogenetic generalised least squares. In: Garamszegi LZ ed. Modern phylogenetic comparative methods and their application in evolutionary biology. Berlin, Springer-Verlag. Pp 105-30.

Symonds MR, Moussalli A 2011. A brief guide to model selection, multimodel inference and model averaging in behavioural ecology using Akaike's information criterion. Behavioral Ecology and Sociobiology 65: 13-21.

Tagawa M, Iwatsuki K 1989. Ferns of Thailand. Bangkok, Royal Forest Department.

Tryon R 1970. Development and Evolution of Fern Floras of Oceanic Islands. Biotropica 2: 76-84.

Tryon R 1986. The biogeography of species, with special reference to ferns. Botanical Review 52: 117-156.

Watkins J, Cardelús C, Colwell RK, Moran RC. 2006. Species richness and distribution of ferns along an elevational gradient in Costa Rica. American Journal of Botany 93: 73-83.

Wickell DA, Windham MD, Wang X, Macdonald SJ, Beck JB 2017. Can asexuality confer a short-term advantage? Investigating apparent biogeographic success in the apomictic triploid fern Myriopteris gracilis. American Journal of Botany 104: 1254-1265.

Wikstrom N, Kenrick P 2000. Relationships of Lycopodium and Lycopodiella based on combined plastid $r b c L$ gene and trnL intron sequence data. Systematic Botany 25:495-510.

Winkworth RC, Wagstaff SJ, Glenny D, Lockhart PJ 2005. Evolution of the New Zealand mountain flora: Origins, diversification and dispersal. Organisms Diversity and Evolution 5: 237-247.

Zaniewski EA, Lehmann A, Overton JMC 2002. Predicting species spatial distributions using presence-only data: a case study of native New Zealand ferns. Ecological Modelling 157: 261-280.

Received 2 December 2016; accepted 4 April 2018

Editorial board member: Matt McGlone

\section{Supplementary Material}

Additional supporting information may be found in the online version of this article:

Appendix S1. List of New Zealand fern species for which data were compiled.

Appendix S2. Descriptions of fern traits and characteristics used in this paper

Appendix S3. Linear mixed effects model AICc model comparison statistics showing the relationships between fern range sizes and species' traits, distribution variables and biostatus for 212 species.

Appendix S4. Boxplot showing the median and variability in range size measured as area of ecological districts occupied for native species shared only with countries in the Pacific, only with Australia, and those shared with other global regions and/or with more than one region.

Appendix S5. Bargraph showing the mean range size ( \pm standard deviation) for endemic and native New Zealand fern species classed as 'Of conservation concern' or not.

Appendix S6. Predicted relationships for unimportant variables included in the full model for the range sizes of 165 species.

The New Zealand Journal of Ecology provides online supporting information supplied by the authors where this may assist readers. Such materials are peer-reviewed and copy-edited but any issues relating to this information (other than missing files) should be addressed to the authors. 